\title{
ŽIVÁ TOPONYMIE ČESKÉHO POHRANIČÍ (NA PŘíKLADU NĚKOLIKA OBCÍ OKRESU JESENÍK)
}

Klíč o vá s lova: toponyma, nestandardizovaná jména, české pohraničí, německá jména

\section{ÚVOD — ČESKÁ POHRANIČNÍ TOPONYMIE'}

Toponymie pohraničí dnešní České republiky měla od té ve vnitrozemí odlišný vývoj. Ten byl dán především historickými okolnostmi osidlování v době středověku ${ }^{2}$ a následným národnostním složením obyvatelstva. Nejstarší místní, ale i pomístní jména (zejména hydronyma) svědčí o slovanském, popř. předslovanském osídlení. Slované se v pohraničí usazovali od 6. až 7. století, především však v úrodnějších (nížinných) oblastech (na Jesenicku na severu při hranicích s Polskem, srov. jména Vidnava, Kraš). České pohraničí, které je z větší části hornaté (což neplatí např. pro jižní Moravu), zůstávalo tak ve vyšších polohách spíše pusté, a to zhruba do konce 12. století. Obydleno bylo až s prríchodem kolonizátorů z území dnešního Německa. Součástí této etapy byla i kolonizace hornická - mnohé oblasti v pohraničí představovaly zdroje nerostného bohatství. Velká část pohraničních zeměpisných jmen je tedy německého původu (srov. na Jesenicku Zuckmantel, dnes Zlaté Hory, nebo Weissbach, dnes Bílý Potok). Novější sídla, která v dalších stoletích vznikala i ve vyšších nadmořských výškách, byla většinou pojmenovávána německy (názvy se odvíjely od etnického složení obyvatelstva dané pohraniční oblasti, které se různilo). Původní slovanské názvy pak podléhaly germanizaci, zejména tam, kde německojazyčné etnikum převládalo, což byl i př́pad Jesenicka (např. r. 1284 Adolcovici, r. 1370 Adilsdorff; dnes Adolfovice; srov. Hosák i Šrámek 1970: 43).

Po roce 1918, kdy se Němci v nově vzniklé Československé republice stali národnostní menšinou, proběhla první vlna počeštování. Na územích, kde bylo německé

\footnotetext{
${ }^{1}$ Tento text vznikl s podporou grantového projektu SGS01/FF/2016-2017 „Nové př́stupy k výzkumu toponymie - na př́ikladu vybraných lokalit Moravy a Slezska“ (poskytovatel Ostravská univerzita, Filozofická fakulta).

2 Podrobněji o kolonizaci a osidlování ve středověku viz Semotanová 2002: 143-161; Maur 1996: 43-49; Klápště 2012: 164-174.
} 
etnikum ve většině a menšinu naopak tvořilo obyvatelstvo české národnosti (např. právě Jesenicko), byla zachována dvoujmennost, případně zde ani pro některá toponyma české dublety nevznikaly. Radikálnější byla až bohemizace toponym po roce 1945 po odsunu Němců z Československé republiky. V současnosti je tedy většina názvů v pohraničí českých, některá jména ovšem i nadále odkazují na svůj německý původ (srov. Matúšová 2015). Na Jesenicku se tak můžeme setkat s místními jmény Rejviz (z něm. Reihwiesen), Rožmitál (z něm. Rosenthal) či Bergov (z něm. Bergau) a s pomístními jmény Edelštejn či Koberštejn.

\section{CHARAKTERISTIKA ZKOUMANÉ OBLASTI, METODA A CÍLE VÝZKUMU}

Předmětem studie je výzkum toponymie ve vybraných lokalitách v pohraničí. Konkrétně jsem se zaměřila na nestandardizovaná pomístní jména ${ }^{3}$ (anoikonyma) několika obcí bývalého okresu Jeseník (Olomoucký kraj, Česká republika). Jedná se o malé horské vesnice Rejviz (něm. Reihwiesen), Dolní Údolí (něm. Niedergrund) a Horni Údoli (něm. Obergrund). Před druhou světovou válkou se zdejší obyvatelé skoro výlučně hlásili $\mathrm{k}$ německé národnosti. Po roce 1945 byly obce vysídleny a němečtí obyvatelé, až na několik výjimek ${ }^{4}$, odsunuti. Vesnice zůstávaly po nějakou dobu neobydlené a pusté (okres Jeseník nepatřil k ekonomicky atraktivním oblastem, vyšší zájem nově prííchozí do pohraničí projevovali o úrodnější, průmyslově vyspělejší či dostupnější okresy). Obce byly osídleny nakonec nejen Čechy a Slováky z vnitrozemí, ale i skupinkami reemigrantů či repatriantů (zejména slovenskými reemigranty z Rumunska). Mnoho domů však zůstalo prázdných, proto zde byli usazováni od roku 1949 uprchlíci z Řecka (řecké a slovanské makedonské národnosti). Na území Rejvízu a Horního a Dolního Údolí tak vznikla silná řecká komunita - oblasti bylo přezdíváno „Malé Řecko“. Nejvíce Řeků se usadilo v Horním Údolí, kam také byla soustředěna většina zůstavších německých rodin. Několik řeckých rodin se během padesátých let odstěhovalo za prací do měst (Zlaté Hory, Krnov), od sedmdesátých let se pak rodiny vracely zpět do Řecka (více viz Sloboda 2003; Joanidis 2006).

Od roku 1960 jsou vesnice Horní Údolí a Dolní Údolí a od roku 1964 i vesnice Rejvíz osadami města Zlaté Hory. Počet obyvatel během druhé poloviny 20. století prudce klesal (zmíněné odchody německých a řeckých obyvatel, ale také odchody mladé a střední generace za prací do průmyslově rozvinutějších oblastí, např. do Ostravy). V současnosti zde má trvalý pobyt jen několik desítek obyvatel. Lokalita

\footnotetext{
${ }^{3}$ Při analýze anoikonym jsem pracovala také se jmény místních částí (např̀. se jmény turistických chat, hradů či pil), a to z toho důvodu, že takováto jména často fungují jako pomístní jména (srov. Pleskalová 1992: 7; Olivová-Nezbedová 1995: 44).

${ }^{4} \mathrm{~V}$ obcích zůstalo asi 18 německých rodin (Joanidis 2006: 40), některé z nich se v šedesátých letech 20. století odstěhovaly do Německa.
} 
slouží spíše k rekreačním účelům (chatařská oblast) a je častým cílem turistů (proto se zde nachází vyšší počet ubytovacích či restauračních zařízení).

Přehledová tabulka osad Rejvíz, Dolní Údolí a Horní Údolí

\begin{tabular}{|c|c|c|c|c|c|}
\hline & Založeno & $\begin{array}{c}\text { První písemná } \\
\text { zmínka }\end{array}$ & $\begin{array}{c}\text { Počet obyvatel } \\
\text { k r. } 1930\end{array}$ & $\begin{array}{c}\text { Počet obyvatel } \\
\text { k r. } 1950\end{array}$ & $\begin{array}{c}\text { Počet obyvatel } \\
\text { k r. 2001 }\end{array}$ \\
\hline $\begin{array}{c}\text { Dolní } \\
\text { Údolí }\end{array}$ & 14. stol. (?) & r. 1720 & $469(* 468)$ & 214 & 19 \\
\hline $\begin{array}{c}\text { Horní } \\
\text { Údolí }\end{array}$ & 14. stol. (?) & r. 1805 & $587(* 577)$ & 19 & 30 \\
\hline Rejvíz & $\begin{array}{c}\text { konec } 18 . \\
\text { stol. }\end{array}$ & r. 1687 & $351(* 344)$ & 207 & 66 \\
\hline
\end{tabular}

Zdroj: Bartoš, Schulz, Trapl 1994.

* $\mathrm{z}$ toho německé národnosti

Cílem studie je posouzení vztahu nestandardizované a standardizované anoikonymie, a to jak té poválečné (české), tak té předválečné (německé). V souvislosti s vrstvou jmen před rokem 1945 jsem se tedy zabývala zachováním německých toponym, ale i jejich př́padnou revitalizací. Vzhledem $\mathrm{k}$ národnostně smíšenému osídlení po druhé světové válce jsem se soustředila také na vliv menšinových jazyků (v tomto př́padě jazyku řeckého) na toponymii daného místa. Hlavní pozornost je pak věnována sémantické a formální utvářenosti nestandardizovaných pomístních jmen.

Materiálovou bázi nestandardizovaných názvů tvořila především jména získaná terénním výzkumem. Následující analýza pracuje se jmény získanými z devatenácti rozhovorů s dvaceti dvěma respondenty ve věku od 22 do 92 let. Výzkum se také opírá o excerpci materiálových zdrojů, a to zejména při zkoumání standardizované vrstvy jmen (a jejího vztahu k nestandardizovaným onymům). Při zjišt'ování standardizované podoby jmen v současnosti jsem vycházela $\mathrm{z}$ webového portálu Českého úřadu zeměměřického a katastrálního Geonames. Zdrojem pro starší (předválečnou) podobu jmen byla dizertační práce z roku 1939 s názvem Die Flurnamen des Kreises Freiwaldau a dále pak soupis zrevidovaných anoikonym, který vznikl ve čtyřicátých a padesátých letech a je uložen na sekretariátu Názvoslovné komise ČÚZK ${ }^{5}$ — kromě bohemizované podoby anoikonyma a jeho přesné lokalizace je $\mathrm{k}$ němu totiž $\mathrm{v}$ soupisu připojena $\mathrm{i}$ jeho předválečná (německá) forma.

\footnotetext{
${ }^{5}$ Za možnost nahlédnutí do těchto dobových pramenů bych chtěla poděkovat tajemnici Názvoslovné komise paní Ireně Švehlové.
} 


\section{STANDARDIZOVANÁ POMÍSTNÍ JMÉNA}

\section{A JEJICH VZTAH K NESTANDARDIZOVANÝM JMÉNU゚M}

Před rokem 1945 byla anoikonymie výzkumné lokality německá. V mapách se výjimečně můžeme setkat i se jmény českými, ta ale pravděpodobně německy mluvícím obyvatelstvem užívána nebyla. Po druhé světové válce došlo k revizi pomístního názvosloví (Šmilauer 1957; Lutterer 1970; Hanzalová 1975). Jména byla nahrazována motivačně novým českým pojmenováním či překládána do češtiny. V př́padě překladu zůstala $\mathrm{z}$ hlediska sémantického a historického kontinuita jmen alespoň zčásti zachovaná (např. Př́ičný vrch < Querberg, Zámecký vrch < Schlossberg). Mezi další postupy patřila rebohemizace a tvoření jmen zvukově podobných. V některých případech bylo německé jméno, již ale v (pravopisně či foneticky) počeštěné podobě, zachováno. To se týkalo zejména názvů hradů a zř́ícenin (Koberštejn, Edelštejn $)^{6}$. Mezi obecné jazykové postupy, které byly při přejmenovávání dodržovány, patřilo nepoužívání archaických a nářečních výrazů — naopak bylo doporučováno čerpat z běžné slovní zásoby, nevyužívání posměšných či přezdívkových názvo̊ a minimalizace honorifikačního motivu (ten se uplatňoval spíše v urbanonymii měst). Již ve druhé polovině 20. století byly některými jazykovědci vysloveny pochybnosti o reálném užívání uměle vytvořených jmen (srov. Hanzalová 1975; Matúšová 1989a, b), např.: „Ukazuje se ovšem, že názvy v mapách odpovídají jen v nízkém procentu názvům užívaným v jednotlivých obcích“ (Matúšová 1989b: 186).

Při výzkumu se ukázalo, že některá standardizovaná anoikonyma jsou mezi obyvateli v komunikaci běžně užívána (cca 34-40\%). Jednalo se především o oronyma, hydronyma, jména hradů a rovněž o jména turistických chat. Často také byla ta toponyma, která v komunikaci označovala významné orientační body, zjednodušována, univerbizována či mechanicky krácena, a vznikala z nich tak jména nestandardizovaná. Standardizovaná jména tedy mohou sloužit jako slovotvorné či sémantické východisko pro jména ,živá“. Mezi takové případy patří nestandardizovaná jména jako Malý Orlik (vrchol ležící pod horou Orlik), Pod Kobrštejnem (rozcestí pod zříceninou Koberštejn), Zlodějky (zkrácený název pro Zlodějské louky), Kobrák (zkrácený název pro zrríceninu Koberštejn), Mecháč (univerbizovaný název pro Velké mechové jezírko) či Podzámek (zkrácený název pro Podzámeckou chatu). S podobnými procesy se ale můžeme setkat i v rámci nestandardizovaných (,„živých“) jmen — např. Hitlerovka (univerbizovaný název pro Hitlerovu zatáčku, oficiálně zatáčka $U$ hřibu).

V turistické oblasti, jakou zkoumané osady představují, jsou nestandardizovaná jména ve velké míře ovlivněna turistickými mapami a ukazateli, a to do té míry, že jsou tyto turistické názvy vnímány jako standardizované. Ta standardizovaná pojmenování, která se v turistických mapách neobjevují, jsou užívána jen sporadicky (určitými skupinami, nap̌r. lesními dělníky).

\footnotetext{
${ }^{6}$ O jazykových postupech při revizi pomístních jmen více viz Matúšová 2015: 235-239.
} 


\section{NESTANDARDIZOVANÁ POMÍSTNÍ JMÉNA}

Při analýze formální a sémantickomotivační stránky nestandardizovaných jmen jsem vycházela zejména z knihy Jany Pleskalové (1989). Autorka v ní využila vztahověmodelovou teorii rozpracovanou již Rudolfem Šrámkem (1999), který ji aplikoval na soubor místních jmen. Zároveň tato teorie vychází ze starších prací Miloše Dokulila (1962), který ale pracoval s apelativní sférou jazyka.

Jana Pleskalová v souladu s Rudolfem Šrámkem rozlišuje u anoikonym čtyři vztahové modely (dále VM), které vyjadřují vztah pojmenovatele k pojmenovávanému objektu. Prvním modelem je VM A, který vyjadřuje polohu (ptáme se kde? odkud?), druhým VM B, který vyjadřuje druh pojmenovávaného objektu (ptáme se kdo? co?), třetím VM C, který charakterizuje pojmenovávaný objekt na základě různých vlastností (ptáme se jaký?), a čtvrtým VM D, který vyjadřuje posesivní vztah (ptáme se čí?). Tyto vztahové modely se mohou spolu nadále kombinovat (napřr. VM A + B, např. U hř́bku; VM C + A, např. Malý Orlík; VM A + D, U Joža). Vztahový model je vyjádřen strukturním modelem, tedy určitým obecným jazykovým modelem. Mezi tyto strukturní modely patří toponymizace objektu, tvoření na základě metaforickém či metonymickém, derivace, kompozice, tvoření dvou- a víceslovných pojmenování, tvoření předložkových jmen a přejímání z cizích jazyků. Strukturní model je formálně ztvárněn určitým strukturním typem (např̀. topoformantem $\left.-i c(e),-n\left(y^{\prime}\right),-o v\left(y^{\prime}\right)\right)$. Podrobněji se ve studii těmto strukturním typům věnovat nebudu.

Konkrétní podoba anoikonymie je ovlivněna různými faktory. Mezi ty hlavní patří charakter krajiny (čím je krajina hornatější, tím méně víceslovných pomístních jmen se zde objevuje), velikost katastru (čím je menší, tím více se zde uplatňují jednodušší - jednoslovná — pomístní jména) a kontinuita osídlení, od které se odvíjí míra zachování původních anoikonym. Pro hornaté oblasti Slezska a severní (severovýchodní) Moravy Jana Pleskalová uvádí jako nejrozšířenější VM A, kterému konkuruje VM D (na severní Moravě často jako vedlejší vztah v rámci předložkového propria). Víceslovná pojmenování by se v nově osídlených oblastech měla, na rozdíl od těch dvouslovných, vyskytovat jen sporadicky. Z hlediska strukturních modelů (dále SM) se pak nejčastěji uplatňují předložková jména a přímé označení objektu. Naopak nejméně se vyskytují pomístní názvy metaforického původu či toponyma odkazující k získávání kulturní půdy, složitým vlastnickým vztahům a vnějším vlastnostem objektů. (Pleskalová 1992: 116-123)

Při vztahověmodelové analýze pomístních jmen osad Rejvízu, Horního Údolí a Dolního Údolí jsem nepracovala s německými jmény (např. Kverberk, Heršberk), vyjma těch, jejichž apelativní základ je běžnou součástí české slovní zásoby (i když třeba jen nářeční či slangové, srov. toponyma Lágr a Pinky), a těch, která obsahují německé osobní jméno (Langrův di̊m, U Helmuta). Výsledek analýzy potvrdil zmíněné závěry Jany Pleskalové. Jako základní vztahový model se nejčastěji 
uplatnil model A (odkazující k poloze) — např. jména U kř́žku, U Joža, Dolina, Pod Kobrštejnem. Druhým nejčastějším modelem byl vztahový model B (př́ímé označení objektu) — např. jména Škola, Opavský most, Roubenky. Vztahový model C (vlastnost) a D (posesivita) se jako základní vztahové modely uplatňovaly jen výjimečně — nap̌r. jméno Mecháč (VM C) a Hitlerovka (VM D).

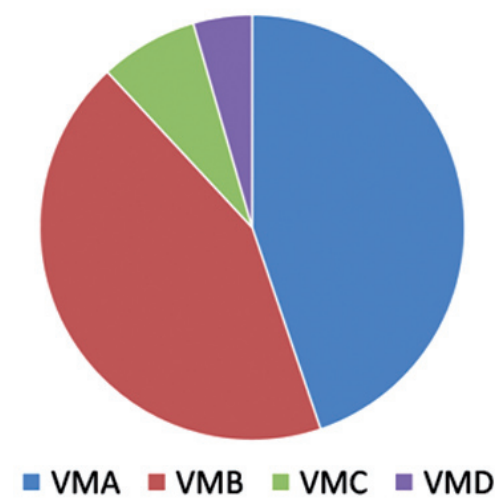

Graf 1. Uplatnění základních vztahových modelů u nestandardizované toponymie

Při zkoumání vedlejších vztahových modelů zůstal zachován primát vztahového modelu $\mathrm{A},+\mathrm{A}+\mathrm{a} \mathrm{B},+\mathrm{B}+$, avšak častěji se jako vedlejší motivace uplatňoval $\mathrm{VM}+$ $\mathrm{D}+$ (např. VM A+D: jména $U$ Dudi, U Milady, či jména VM D + B: jména Galova louka, Kucrův mlýn).

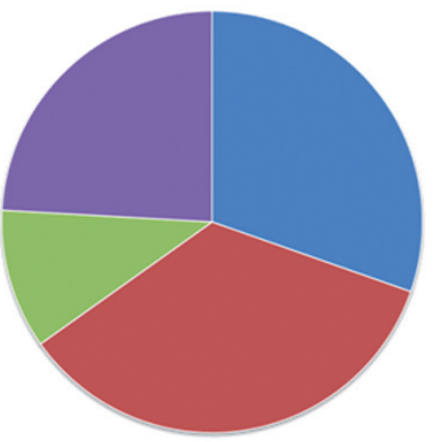

$\square \mathrm{VMA},+\mathrm{A}+\quad \mathrm{VMB},+\mathrm{B}+\square \mathrm{VMC},+\mathrm{C}+\square \mathrm{VMD},+\mathrm{D}+$

Graf 2. Uplatnění základních a vedlejších vztahových modelů u nestandardizované toponymie

Pomístní jména byla analyzována rovněž z pohledu strukturněmodelového. Obyvatelé nejčastěji užívali předložkových jmen (spojení předložky a substantiva, případ- 
ně substantivizovaného adjektiva či derivovaného substantiva) - např. U Milady, U Jaštíki̊, U soutoku, Pod pomníkem. Nejčastěji se ve jménech uplatňovala předložka $U$. Druhým nejobvyklejším modelem bylo dvouslovné pojmenování (ve spojení adjektivum, př́padně derivované adjektivum a substantivum) — Malá hospoda, Polský dům, a př́mé označení objektu (substantivum, derivované substantivum) - např. Mlýnky, Obchod, Dolina. V rámci derivace se nejčastěji můžeme setkat s deminutivizací a pluralizací (případně kombinací obojího). Pro názornost byla do následujícího grafu dodána i jména německého původu (Ločesberk, Šozhýbl), o nichž viz dále.

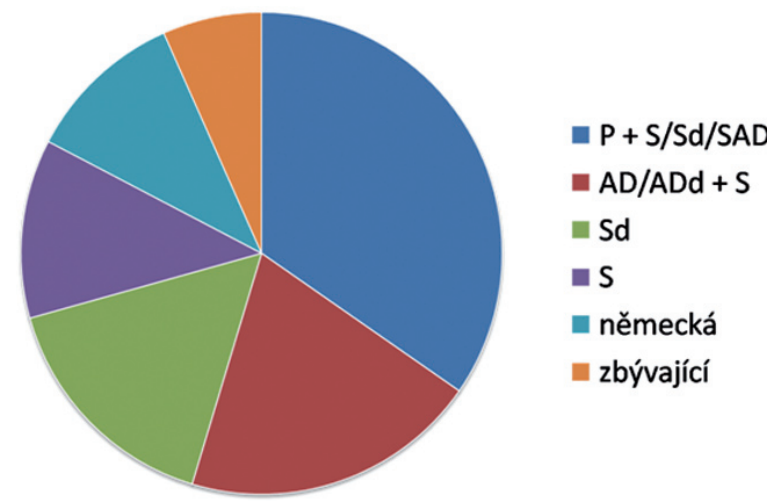

Graf 3. Uplatnění strukturních modelů u nestandardizované toponymie (vysvětlivky: $\mathrm{P}=$ předložka, $\mathrm{S}=$ substantivum, $\mathrm{Sd}=$ substantivum derivované, $\mathrm{SAD}=$ substantivizované adjektivum, $\mathrm{AD}=$ adjektivum, $\mathrm{ADd}=$ adjektivum derivované)

Jak již bylo naznačeno, v nestandardizované toponymii se vyskytují také jména německého původu. Ta lze rozdělit do několika skupin.

První skupinu tvoří německá jména (nejčastěji oronyma), která reflektují předválečnou toponymii. Většinou jde o standardizované názvy, se kterými se můžeme setkat $\mathrm{v}$ předválečných mapách či soupisech ( $\mathrm{v}$ jednom př́ípadě se dochovalo i předválečné nestandardizované oronymum - Ločesberk). Užívají je především starousedlíci z Horního Údolí. V této obci byli po válce vedle obyvatel řecké národnosti soustředěni právě obyvatelé národnosti německé, čímž zde byla udržena určitá sídelní kontinuita, která je základní podmínkou pro zachování německých jmen (srov. Matúšová 1989a, b, 2015; Pleskalová 1989, 1999). Tato předválečná toponyma byla používána především obyvateli s německými kořeny, případně několika českými/slovenskými/řeckými starousedlíky, kteří byli v kontaktu s německojazyčným etnikem. Později př́ichozí či rekreanti zmiňovali většinou pouze pasivní znalost těchto jmen nebo jména neznali vůbec. Do první skupiny německých jmen patří anoikonyma jako Špicberk (hora, dnes Jeleni vrch, ovšem vedlejší vrchol Špičák, dále jméno Pod Špičákem; původně Spitzberg), Kverberk (hora, dnes Př́čný vrch; původně Querberg), Šozhýbl (hora, dnes Zámecký paho- 
rek; původně Schooshübel//Schlosshübel) či Mariahilf (poutní místo, dnes Panna Maria Pomocná; původně Mariahilf).

Do druhé skupiny řadím takové názvy, které vycházejí z německých osobních jmen (at' už předválečných či poválečných) - např. Kucrův mlýn (podle sochaře a malíře Bernarda Kutzera), U Helmuta či Galova louka (obojí podle místních obyvatel). Tato jména jsou opět známa spíše starousedlíkům, ale pronikla i mezi mladší generaci (zejména ta, která v sobě nesou informaci o jménu významné osobnosti či jménu obyvatele, který zde pobýval i po druhé světové válce, nap̌r. Kucrův dưm, U Helmuta).

Třetí skupinu německých pojmenování představují taková jména, která sice vycházejí z německého jazyka, ovšem existují v současné slovní zásobě (spisovné, ale i nářeční či slangové) jako přejímky — jména Lágr a Pinky.

Zajímavým fenoménem je revitalizace německých názvi̊ mezi mladší generací, nově příchozími a rekreanty. $V$ případě anoikonymie jsou německé názvy oživovány spiše jen sporadicky (napřs. skupinou mladé generace užívané zkomolené jméno Šozhykl - mezi starousedlíky z vedlejší vesnice známé jako Šozhýbl — vycházející z německého předválečného jména Schooshübel//Schlosshübel, v současnosti Zámecký pahorek). Častěji se však s touto revitalizací můžeme setkat v rámci nestandardizované vrstvy místních jmen, tedy oikonym (např. Grunt místo Horního a Dolního Údolí, dřive Obergrund // Horní Grunt a Niedegrund // Dolni Grunt).

Vzhledem $\mathrm{k}$ poválečnému osídlení a přítomnosti řeckého etnika (po válce se jednalo o zhruba 150 rodin, tj. přes 450 osob, některé odhady hovoří o 600-800 obyvatelích) jsem se rovněž zaměřila na možnou existenci řeckých jmen v nestandardizované anoikonymii. Většina řeckých rodin osady Rejvíz a Horní a Dolní Údolí opustila (odchody za prací či zpět do Řecka). V současnosti zde zůstaly pouze tři rodiny (Horní Údolí, Rejvíz). Při rozhovorech s místními obyvateli řecké národnosti ovšem vyplynulo najevo, že nově příchozí po nastěhování řecká toponyma netvořili, ale používali standardizovaná jména česká (v př́ípadě Horního Údolí, kde žilo i německé etnikum, rovněž jména německá), i když někdy zkomoleně (vinou pro Řeky obtížné výslovnosti některých českých hlásek, např. [h] > [ch]). Řecká jména se uplatnila pouze $\mathrm{v}$ př́padě označení jednotlivých domů podle majitelů (v podobě předložky $U+$ řeckého osobního jména), např. jméno $U$ Tiliny, avšak jejich znalost a uživání bylo (a je) omezeno pouze na obyvatele řecké národnosti v Horním Údolí. V současnosti tak tato jména fungují pouze $\mathrm{v}$ rámci jedné sociální skupiny, konkrétně tedy pouze $\mathrm{v}$ rámci jedné řecké rodiny.

\section{ZÁVĚRY}

V českém pohraničí (v oblasti Jesenicka) se v komunikaci místních obyvatel uplatňují jak pomístní jména standardizovaná, tak i jména nestandardizovaná. Důvodem zachování a užívání standardizovaných jmen je úzký vztah těchto názvů 
k realitě, kterou odráží (na Zámeckém pahorku leží zřícenina, Nové štoly v místě štol, od pramene Černé Opavy vede Opavská cesta, na ní leží Opavská chata apod.), dále pak používání slov z běžné slovní zásoby. Frekventovaná standardizovaná jména často přecházejí mezi jména nestandardizovaná, a to za využití univerbizace či mechanického krácení.

V pohraničí se $\mathrm{v}$ nestandardizované vrstvě jmen vedle českých toponym objevují také toponyma německá. Podmínkou pro jejich zachování je sídelní kontinuita. $\mathrm{V}$ některých př́ípadech se také můžeme setkávat $\mathrm{s}$ revitalizací starších německých názvů. Je otázkou, zda je toto oživování záležitostí určitého návratu ke kořenům (který se odvíjí od postupné detabuizace odsunu Němců a vůbec historické př́ítomnosti německého etnika), nebo zda revitalizace sleduje spíše ekonomické či komerční cíle (především u chrématonym), kdy se majitelé mohou pokoušet zprostředkovat turistům ,autentický“ zážitek, a podpořit tak cestovní ruch v dané lokalitě. Vliv řecké národnostní menšiny na toponymii dané oblasti nebyl potvrzen. $\mathrm{V}$ př́ípadě jazykových menšin a jejich role $\mathrm{v}$ utváření toponymie pravděpodobně hrají důležitou roli proces asimilace obyvatel dané etnické skupiny a nepřerušená sídelní kontinuita, tedy délka jejich pobytu v lokalitě.

Z hlediska formálního a sémantického jsou pak nestandardizovaná toponyma zjednodušována. Motivačně vycházejí z polohy či z druhu pojmenovávaného objektu (v rámci těchto motivů pak vypovídají o vlastnických vztazích). Formálně se můžeme setkávat zejména s předložkovými a dvouslovnými jmény a s př́mými pojmenováními (vzniklými toponymizací či derivací). Celkově lze říci, že se znalost a užívání toponymie omezuje spíše na centra obcí. Jednotlivé lesy, louky či pěšiny již nejsou pojmenovávány. Jako orientační body v obci fungují jména obyvatel/ vlastníků objektů či chrématonyma (v turistické oblasti většinou názvy penzionů, hotelů a restauračních zařízení).

\section{LITERATURA}

Bartoš J., Schulz J., Trapl M. 1994: Historický mistopis Moravy a Slezska v letech 1848-1960, 13: Okresy Bruntál, Jesenik, Krnov, Univerzita Palackého, Olomouc.

Dokulil M. 1962: Tvoření slov v češtině. 1: Teorie odvozování slov, Československá akademie věd, Praha.

Gans H. 1939: Die Flurnamen des Kreises Freiwaldau, Dissertation, Hohen Philosoph. Fakultät der Deutschen Universität, Prag.

Geonames, Český úřad zeměměřický a katastrální c2010, geoportal.cuzk.cz/geoprohlizec (přístup 30.08.2016).

Hanzalová L. 1975: Revize pomistního názvosloví po r. 1945, „Zpravodaj Místopisné komise ČSAV“ 16, s. 600-605.

Hosák, L., Šrámek R. 1970: Místní jména na Moravě a ve Slezsku, I: A-L, Academia, Praha.

Joanidis S. 2006: Rejviz a báje z okolí, Rula, Rejvíz.

Klápště J. 2012: Dlouhý pomalý běh středověké kolonizace, [v:] Proměny českých zemí ve středověku, Nakladatelství Lidové noviny, Praha, s. 164-174. 
Lutterer I. 1970: K zásadám poválečné úpravy pomistního názvoslovi v českém pohraničí, [v:] Š. Krištof (red.): Zborník materiálov zo sympózia o teoretických a metodologických otázkách onomastiky a II. slovenskej onomastickej konferencie v Nitre 22.-24. mája 1969, Slovenské pedagogické nakladatel'stvo, Bratislava, s. 151-156.

Matúšová J. 1989a: Ustalováni pomistnich jmen v oblasti česko-německého jazykového kontaktu po r. 1945, [v:] M. Majtán (red.): Aktuálne úlohy onomastiky z hl 'adiska jazykovej politiky a jazykovej kultury, Jazykovedný ústav Ludovíta Štúra Slovenskej akadémie vied, Bratislava, s. 119-126.

Matúšová J. 1989b: Vývoj a standardizace pomistnich jmen a urbanonym v českém pohraničí, „Naše řeč“ 72 , s. 179-187.

Matúšová J. 2015: Německá vlastni jména v češtině, Nakladatelství Lidové noviny, Praha.

Maur E. 1996: Středověká kolonizace, [v:] B. Pravdová (red.), Dějiny obyvatelstva českých zemí, Mladá fronta, Praha, s. 43-49.

Olivová-Nezbedová L. 1995: Pomistní jména v Čechách: O čem vypovídaji jména polí, luk, lesů, hor, vod a cest, Academia, Praha.

Pleskalová J. 1989: Vývoj anoikonymie v oblastech nově osídlených po roce 1945, [v:] M. Majtán (red.): Aktuálne úlohy onomastiky z hl'adiska jazykovej politiky a jazykovej kultury, Jazykovedný ústav Ludovíta Štúra Slovenskej akadémie vied, Bratislava, s. 113-118.

Pleskalová J. 1992: Tvořeni pomistních jmen na Moravě a ve Slezsku, H \& H, Jinočany.

Pleskalová J. 1999: Česká pomístní jména v diachronním pohledu, „Acta onomastica“ 40, s. 186-195.

Semotanová E. 2002: Osídlení českých zemí, jeho vývoj a struktura, [v:] Historická geografie Českých zemí, Historický ústav AV ČR, Praha, s. 143-161.

Sloboda M. 2003: Language Maintenance and Shifts in a Greek Community in a Heterolinguistic Enviroment: The Greeks in the Czech Republic, „Journal of the Hellenic diaspora“ 29, s. 5-33.

Šmilauer V. 1957: Revise českých pomistnich jmen, „Naše řeč“ 40, s. 260-277.

Šrámek R. 1999: Úvod do obecné onomastiky, Masarykova univerzita, Brno.

\section{POPULAR TOPONYMS IN THE CZECH BORDERLANDS (ILLUSTRATED WITH SEVERAL VILLAGES IN THE DISTRICT OF JESENÍK)}

\section{SUMMARY}

My contribution focuses on non-standardized (popular) forms of toponyms in several villages in the district of Jeseník (Rejvíz, Horní Údolí, Dolní Údolí - Czech Republic). This region was settled by the Germans in the Middle Ages. After their expulsion in 1945 the small villages were resettled mostly by refugees from Greece. Nowadays the localities are not fully inhabited (most of the Greek population left the region in the 1970s) and it became more of a holiday resort and a tourist area.

Non-standardized (popular) field-names — collected via field research (during 2016) — are confronted with standardized German forms used before 1945, and with currently used Czech forms. The goal of the study is to analyse formal and semantic features of the non-standardized filed-names. The analysis is based on the concept of relation and structural model, which was described by Jana Pleskalová and Rudolf Šrámek. I also deal with the German place names and their preservation and revitalization. In the last part of my work I study influence of national minority on the field names.

Key w o rd s: toponyms, non-standardized names, Czech borderlands, German names 